\author{
JACEK RUDEWICZ \\ University of Szczecin, Poland \\ KrzyszTof Sala \\ Pedagogical University of Krakow, Poland
}

\title{
New professional competencies in the era of WEB 2.0 and 3.0 and the dissemination of ICT
}

\begin{abstract}
The purpose of this article is to identify and describe the new, yet relatively poorly known, competencies related to WEB 2.0 and 3.0 and the dynamically changing organisational environment influenced by the development of ICT. The article's content can be used (application purpose) to draw attention to the necessity of active searching for new competency areas by trainers and teachers. To achieve this aim, two research tasks were undertaken. The first was a literature review and explanation of the concepts related to the research subject. This theoretical foundation then served as a starting point for an attempt to create a list of professions and related competencies corresponding to the needs of WEB 2.0 and 3.0. The results of this are presented in a tabular form.
\end{abstract}

Keywords: entrepreneurship; internet; personal development; social media

Received: 26 October 2020

Accepted: 2 March 2021

\section{Suggested citation:}

Rudewicz, J., Sala, K. (2021). New professional competencies in the era of WEB 2.0 and 3.0 and the dissemination of ICT. Przedsiębiorczość - Edukacja [Entrepreneurship - Education], 17(1), 19-34. https://doi.org/10.24917/20833296.171.2

Introduction: conceptual apparatus

The article aims to identify and describe a set of competencies related to the still-new phenomenon of WEB 2.0 and 3.0 and the changing organisational environment influenced by the dynamic development of ICT. The goal is to create a definition for professions related to creating the material on the internet. The article's application goal is to indicate new competency areas essential for preparing training and conducting classes. The tasks to be accomplished included reviewing the literature and clarifying the concepts related to the research subject, and attempting to create a list of new professions and related competencies on this theoretical basis. 
In their synthesising study devoted to definitional issues, T. Garavan and D. McGuire (2001) proposed an approach to defining competencies based on an individual: their characteristics, what they have learnt or their innate ability, and the organisation's perspective. The concepts indicate conflicting views on teaching dominance in their shaping or on an individual's innate predispositions. Competencies that characterise an organisation are a resource influencing its competitiveness, while individual employees' competencies are specific to a given organisation. In the 1960s, G.E. New (1966) divided the notion of 'professional competencies' into organisational and individual. From the organisation's point of view, professional competency is the motivation and ability to use one's skills, knowledge and professional preparation in a way that is useful for the organisation and manifested in the behaviour of employees. From an individual perspective, competency covers an employee's skills, knowledge and professional preparation and constitutes a subclass of broader social competencies. Garavan and McGuire (2001), while trying to define competencies, divided them into three groups following other writers.

Employee-oriented definitions:

1. Behavioural characteristics of an individual that are causally related to efficiency and/or better job performance. It means that there is evidence to show that having these characteristics leads to greater efficiency and/or better performance at work (Boyatzis, 1982),

2. Essential characteristics of an individual that are causally related to a criterion that includes the person's efficiency and/or better job performance or situation (Spencer L.M., Spencer S.M., 1993),

3. High-performance levels or skills are a relatively stable set of behaviours that ensure excellent workgroup performance in more complex organisational environments (Schroder, 1989).

Workplace-oriented definitions:

4. Professional competencies are the abilities to perform activities within the profession or function to the level expected in the workplace (Management Charter Initiative, 1990),

5. Professional capacity (Nordhaug, Gronhaug, 1992),

6. An action, behaviour or result that an individual should be able to demonstrate (Training Standards Agency, 2000).

Multi-dimensional definitions:

7. The ability to apply knowledge, understanding, practical skills and thinking to achieve effective results against employment standards. It also includes problem-solving and sufficient flexibility to meet changing requirements (NCVQ, 1997),

8. Skills, knowledge and understanding, characteristics and attributes, sets of values, beliefs and attitudes that lead to effective management outcomes in a given context, situation, or role (Woodall, Winstanley, 1998).

The concept of competency as a synonym for skills was used in 1973 (job competencies), and the author credited with introducing this term is D.C. McClelland, a psychologist who researched motivation and entrepreneurship (Mikuła, Pietruszka-Ortyl, 2007; Orlińska-Gondor, 2006). Competencies are defined by the formal and informal effects of education, which include knowledge, i.e. a set of facts, laws, theories, principles and experiences acquired or constructed independently; and skills, i.e. the readiness to use 
this knowledge in the implementation of tasks. In turn, social competencies are the ability to design and shape one's development and autonomous and responsible participation in social and professional life (Kwiatkowski, 2014). According to another approach, "competency is a conglomerate of acquired knowledge in a given field (what I know), skills (procedural knowledge - I know how and I can), attitudes (I want and am ready to use my knowledge)" (Kossowska, Sołtysińska, 2002).

Therefore, competencies are an ambiguous concept. A commonly accepted definition has yet to be adopted in the management theory and practice. Definition and ordering the issues has undoubtedly taken over some academic works. For example, T. Rostowski (2002) proposes eight categories of competencies, i.e. talents, skills, knowledge, physical competencies, styles of action, personality, principles and values, and interests. Another example is the division into essential competencies and executive competencies (Filipowicz, 2004). The basic ones include cognitive (e.g. creativity, the flexibility of thinking), social (e.g. communicativeness, negotiation), and personal (e.g. commitment, perseverance). In turn, executive competencies include business (e.g. knowledge of the industry, sales techniques), company (e.g. identification, professional knowledge), and managerial (e.g. leadership, organising) (for more, see Berek, 2016).

From the article's perspective, it is essential to distinguish between hard and soft and general and professional competencies. Soft competencies are more task-oriented, divided into personal or social (personal or group context) such as psychosocial and behavioural skills. Soft competencies are a combination of skills in building interpersonal, social relationships, communication, character or personality traits, attitudes, professional attributes, and social and emotional intelligence, enabling employees and entrepreneurs to efficiently navigate their work environment and achieve goals while supplementing hard competencies. The Collins Dictionary defines the term 'soft skills' as "desirable qualities for certain forms of employment that are not dependent on acquired knowledge: these include reasonableness, the ability to deal with people, and a positive and flexible attitude" (Collins Dictionary, 2020, 15 November). Hard competencies, in turn, also known as technical skills, are related to a specific task or situation. They include understanding and proficiency in methods, processes, procedures and techniques. As opposed to soft skills, they are more easily measurable and more specific. As S.M. Kwiatkowski writes, in the process of education, they are closer to the formal kind. "It is worth noting that after passing the relevant exams, the competencies developed during formal education become qualifications. Competencies that can be acquired in non-formal and informal education could be called qualifications but must undergo validation procedures (checking, proving)" (Kwiatkowski, 2014: 25). Professional and soft competencies complement each other, combined with a comprehensive set of employee attributes, verified at the stage of employee recruitment and performance evaluation. Although the latter is more dependent on human personality and difficult to measure - psychology comes to the rescue - they can be shaped through appropriate education and training (coaching). Their preferred proportions by an employer depend on the job position and the organisational context. The concept of qualifications is ambiguous and difficult to systematise. In Poland, soft skills are not adequately developed by the formal education system at all levels, even though their role in a dynamic and changing business environment is growing. 
WEB 1.0, 2.0 and 3.0, or maybe 4.0 ?

The first implementation of the global internet network is described as WEB 1.0, which according to T. Berners-Lee (1998), can be considered a 'read-only internet'. In other words, this early form made it possible for us to find and read information; it developed between 1989 and 2005. It did not provide many opportunities for user and content interaction, as the first generation of WEB networks were static pages that only provided content. In other words, the early web allowed information to be searched for and read.

Computerisation and the spread of internet communication and electronic services have swept like a wave through the economy, culture and society. They have changed the way organisations operate from supply chain management through marketing and information resources to mundane office work. They have created new professions, directly and indirectly, dependent on digital technology. On the labour market and the market for educational services, not only have basic IT competencies from the past become important, i.e. for the operation of still imperfect operating systems, spreadsheets, accounting, office and specialist programs, e.g. CAD, but over several years, the passage of a second wave related to progress in computer science has been found. This progress is a quantitative change, i.e. it relates to the universal access to the network from anywhere, an increase in computing power, and memory capacity exceeding terabytes. This wave is also qualitative in terms of ease of working and using the virtual sphere. It concerns to a greater extent interpersonal and marketing communication, socialisation of the internet and the virtualisation of certain areas of life, e.g. dating, trade, banking and finance. The internet has become a competitive medium for traditional media and an attractive medium for information exchange. Communication platforms began to influence interpersonal and business relationships, and even social awareness and political choices. This wave, known as Web 2.0, created the need to develop new competencies and skills while opening the door for content creators who had not yet had the opportunity to create and present in front of an audience. The definition of WEB 2.0 appeared in 2005. Passive recipients of the internet had now become co-creators and active participants. They were given tools to comment, rate, publish their texts, photos and videos. They were allowed to communicate with each other, create virtual groups according to interests and views on a given topic. E-commerce and the sharing economy gained traction (Rudewicz, 2019). The concept of WEB 2.0 is associated with the popularisation of social media requiring a personal virtual profile and managing it successfully.

The advent of the internet under the banner of WEB 2.0 has had many effects. The medium's openness and the availability of streaming have increased, attracting viewers of conventional television favouring vlogging (video blog) and VOD. Traditional magazines are losing readers to blogs and online editions. Conventional marketing channels exist, but they are extended by e-marketing based on statistics and research on customer behaviour. There is also a comprehensive strengthening of traditional marketing communication channels by supplementing them with emotionally engaging social media communication. Besides, tools such as Google Analytics, Double Click and Facebook Insight combine a given person's internet activity, e.g. websites visited, their movements, a history of viewed pages and consumer choices. Mobile devices, in turn, allow users to be tracked not only in the virtual sphere but also in geographical space through GPS 
locations. People who want to run a business to create their brand or privacy need to know how to protect their data. A modern person should know how Web 2.0 functions, understand the meaning of so-called big data and internet dangers, e.g. fake news. The contemporary internet and new media require creativity and specific skills. HR specialists mention several future professions, including vloggers - people presenting film materials on various topics, and bloggers - people writing texts on the web closer to self-publishing, personal publishing and journalism. Marketers and market researchers must understand the operation of analytical platforms and a virtual crowd's behaviour and create attractive messages to given market segments and websites. People who can navigate through the maze of information, produce relevant database queries and navigate internet resources have an advantage over those who do not understand a search engine's language. The Web 2.0 wave continues to roll out solutions based on artificial intelligence, while the need for help in the dark side of Web 2.0, addictions and information overload have appeared. For educators in the academic world, the Web 2.0 wave poses a challenge concerning the education system's inertia. F. Karakas (quoting many other authors) goes further in his considerations, transferring changes in communication and the increase in interactions between clients and enterprises to the whole of society. He calls this phenomenon World 2.0, i.e. internet platforms (no longer websites) that enable the exchange of information between users and the sharing of intangible assets, e.g. photos, films and music. Participants can create together, solve problems, carry out projects, collect money, make purchases, and find entertainment. The author described World 2.0 according to five features, briefly discussed below:

1. Creativity. The importance of creativity and innovation on business and online platforms is growing. Organisations are trying to introduce creative ways of organising and working, such as building connections through employee networks, using collective intelligence, or creating collective intelligence in multi-disciplinary teams.

2. Networking - connecting to the internet - the global brain - providing access to global online information resources. Networking is a technological infrastructure and a mindset that connects geographically distant points (e.g. people, databases) to increase access to information resources. The distinction between learning, work, play and leisure is blurring as mobile devices are ubiquitous, and culture is 'always on'. So we move to a fully hyperlinked society where the number of network connections exceeds the number of people connected.

3. Collaboration. Billions of people and entities are connected in a network to cooperate and participate in innovation, creation and social development thanks to a virtual global internet platform. They exchange ideas and intangible values, develop art, culture, science and education.

4. Convergence. Various media, such as radio, television, newspapers, telephone, mobile devices and the internet, merge into one global news channel. The new world in the twenty-first century is becoming more intense, global and dynamic (global village). Breaking down economic borders between countries, bridging distances through telecommunications, rapid technological change, labour mobility and cultural diversity, the proliferation of wireless, fibre optic, and broadband technologies create new challenges and opportunities for professionals and managers worldwide.

5. Community - using online platforms and new media for social change and community benefits. New media, also known as 'social media', have been widely used 
by social movements to educate, organise, communicate, lobby, protest, raise funds, democratise information and raise public awareness. It can also be called online social activism.

WEB 3.0 comes from the basics and assumptions describing WEB 2.0 and is its extension. The term was first coined by J. Markoff of the New York Times, who described it as the third generation of the web in 2006 (Spivack, 2011). Web 3.0 can also be referred to as 'executable web'. The basic idea of WEB 3.0 is defining the data structure and linking it to search, automate, integrate and reuse it more effectively in various applications. The WEB 3.0 concept is related to semantic networks. It means, for example, that when searching on the web, the search engine, thanks to unique algorithms, will associate our query with other information about us on the web and provide us with additional information related to the query, e.g. additional locations or events. The search is more contextual and personalised.

Table 1. Internet development stages

\begin{tabular}{|c|c|c|c|}
\hline $\begin{array}{c}\text { Internet } \\
\text { development } \\
\text { stage }\end{array}$ & WEB 1.0 & WEB 2.0 & WEB 3.0 \\
\hline Timeframe & 1996-2004 & $2004-2016$ & $2016+$ \\
\hline Main feature & $\begin{array}{l}\text { HTML hypertext } \\
\text { network }\end{array}$ & social network & semantic network \\
\hline $\begin{array}{l}\text { Author of the first } \\
\text { definition }\end{array}$ & Tim Berners Lee & $\begin{array}{l}\text { Tim O’Reilly, Dale } \\
\text { Dougherty }\end{array}$ & Tim Berners Lee \\
\hline Feature & $\begin{array}{l}\text { one-way } \\
\text { communication }\end{array}$ & $\begin{array}{l}\text { multilateral } \\
\text { communication }\end{array}$ & $\begin{array}{l}\text { a network of } \\
\text { dynamic applications } \\
\text { (Executable Web) }\end{array}$ \\
\hline Number of users & millions & billions & $\begin{array}{l}\text { billions (including } \\
\text { devices) }\end{array}$ \\
\hline $\begin{array}{l}\text { Interaction } \\
\text { method }\end{array}$ & $\begin{array}{l}\text { information from the } \\
\text { server }\end{array}$ & $\begin{array}{l}\text { participation and } \\
\text { interaction }\end{array}$ & engagement \\
\hline $\begin{array}{l}\text { Communication } \\
\text { direction }\end{array}$ & in one direction & bidirectional & $\begin{array}{l}\text { virtual multi-user } \\
\text { environment }\end{array}$ \\
\hline Content author & content publisher & users & $\begin{array}{l}\text { users create an app that } \\
\text { allows others to interact } \\
\text { and publish content }\end{array}$ \\
\hline Content-type & static & dynamic & AI, 3D \\
\hline Identity & personal websites & $\begin{array}{l}\text { blogs and personal } \\
\text { internet profiles }\end{array}$ & $\begin{array}{l}\text { semiBlogs, semantic } \\
\text { browsers, e.g. Haystack }\end{array}$ \\
\hline Main website type & providing information & social media & $\begin{array}{l}\text { semantic internet } \\
\text { forums }\end{array}$ \\
\hline User list & buddy list, address book & online social networks & $\begin{array}{l}\text { semantic social } \\
\text { information }\end{array}$ \\
\hline
\end{tabular}

Source: Model ewolucji internetu: wersja 0.3 (2010)

WEB 3.0 is an intelligent network that suggests, gives and retrieves information for the recipient. Another feature of WEB 3.0 is integrating many devices equipped with small WiFi transmitters installed in objects around us - the so-called Internet of Things (IoT). 
It will enable the improvement of many aspects of life, from our flats to cities (Smart City) where, for example, litter bins or street lamps will be equipped with sensors informing us when they are full or if there is an available parking space. Another distinguishing feature of the new internet generation is blockchain technology ('public register' would also be an appropriate term), enabling secure online transactions and payments with virtual currencies such as Bitcoin. By simplifying technological issues, this technology enables peer-to-peer transactions. It can contribute to the spread of virtual payments and authentication through, for example, 'fingerprinting', which is a step towards internet democracy and administration.

\section{Professions and corresponding competencies in the era of digitisation and new media}

The summary in Table 1 shows that the WEB 2.0 internet and the symptoms of the next phase in the internet evolution are already appearing as a 'medium' of multidimensional communication - information exchange in the form of verbal, visual and audiovisual messages in various traditional and new forms, e.g. blogs, podcasts and even memes. Many communication functions follow from this. Apart from the typical information function, it creates bonds, social relations, exchanges of views, networking, image creation, creativity, the creation of virtual products and the expansion of marketing tools as part of promotion and consumer research. On this basis, an attempt was made to outline a framework for qualifications related to new professions in the WEB 2.0+ era. Table 2 contains a list of professions (Kwiatkowski, Woźniak, 2003), which have emerged with the development of the internet and new media. Vocabulary and terms found among those professionally involved in creation on the internet and social media are used to describe it. They are often borrowings from English, and there are no verbal equivalents in Polish.

According to PBI reports, $80 \%$ of Poles use the internet, which, in 2020, was 27.2 million people. Poles made 66.6 billion website views, and the average internet user spent almost two hours online daily. The popularisation of the internet on various types of devices among households creates enormous market space for development. For several years, the level of computer equipment in enterprises has remained constant, amounting to approximately $96 \%$. In 2012, 36\% of enterprises used computers with internet access; in 2019 , it was $43.2 \%$ (GUS). The use of a website to establish communication with the business environment grows with the size of the enterprise, and the most common way of using it is for the presentation of products, goods, services and price lists. Among the smallest enterprises (10-48 employees), 66\% use a website as a showroom, while among medium-sized (51-249 employees) and the largest (250 or more) - 99\%.

In terms of WEB 2.0, 22\% of all enterprises use links to social media on their websites, with $55.7 \%$ of the largest enterprises. Collecting and analysing information on website visitors' behaviour is performed by $13.2 \%$ of all companies, $11.2 \%$ of small companies, $22.1 \%$ of medium-sized companies, and $32.4 \%$ of large companies. Narrowing down the analysis of enterprise activity to examples of social media (SM), social networking sites are run by $35.4 \% ; 32.2 \%$ of small companies, $44.6 \%$ of medium companies, and $67.7 \%$ of large companies (Table 3). In total, $13.3 \%$ of all companies use websites enabling multimedia; $10 \%$ of small companies of 10-49 employees, $20.7 \%$ of medium-sized companies of 50-249 employees and 46.5\% of large companies of 250 employees and more. 


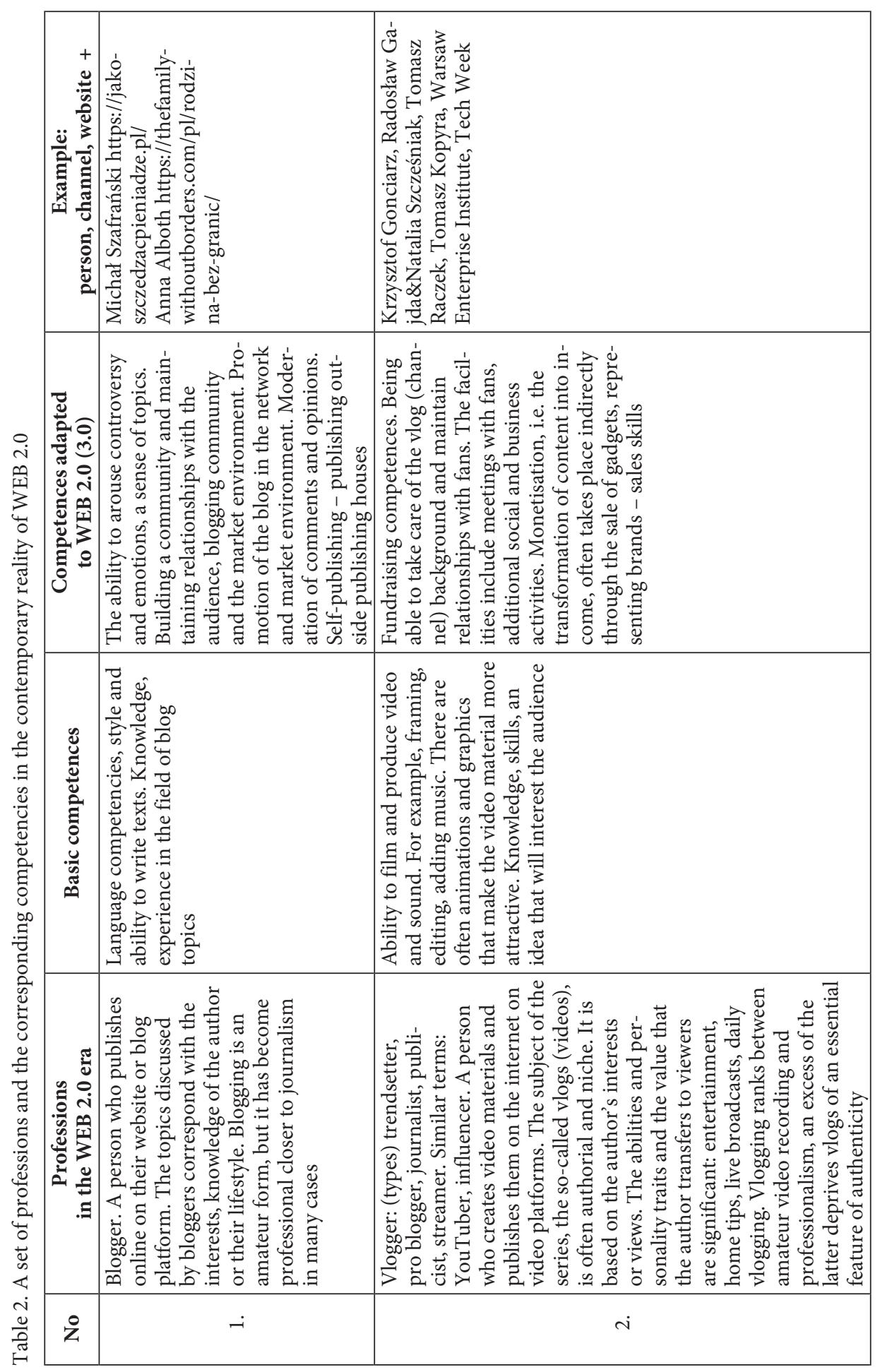




\begin{tabular}{|c|c|c|}
\hline 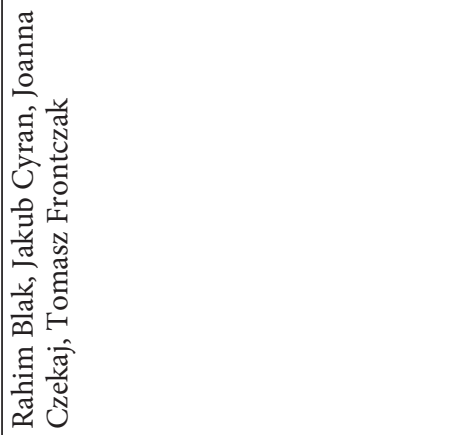 & 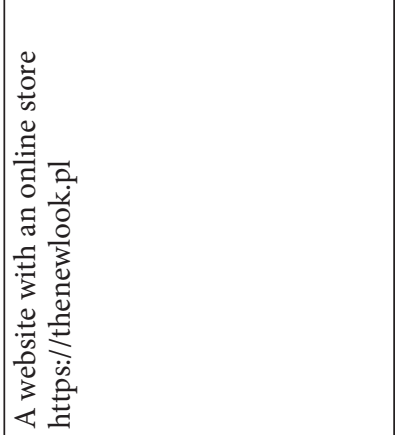 & 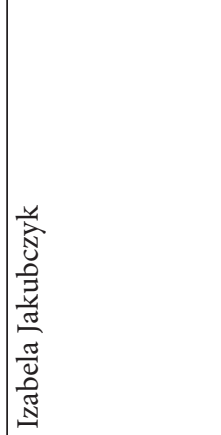 \\
\hline 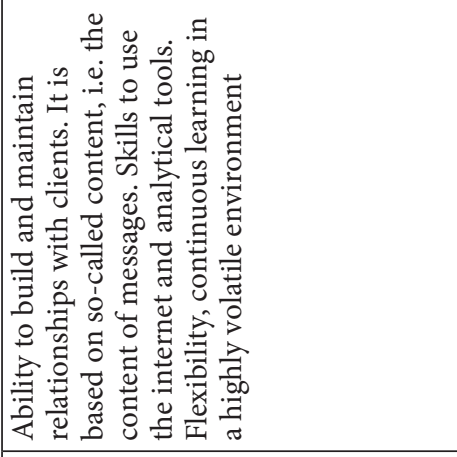 & 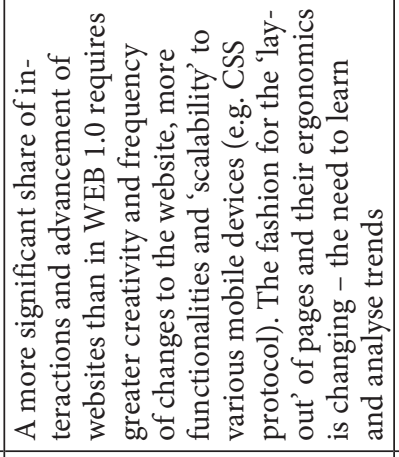 & 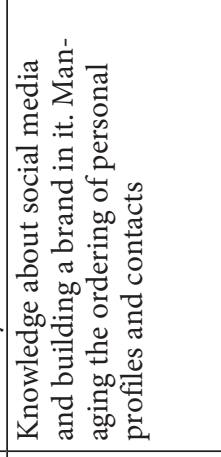 \\
\hline 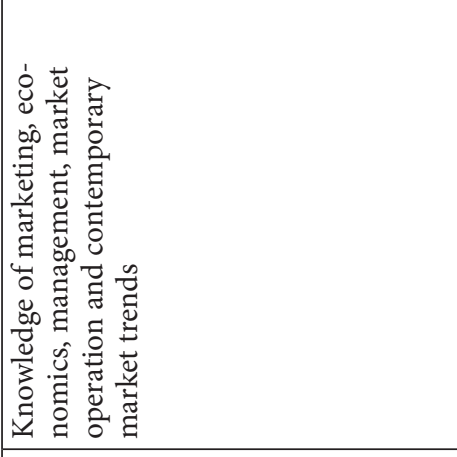 & 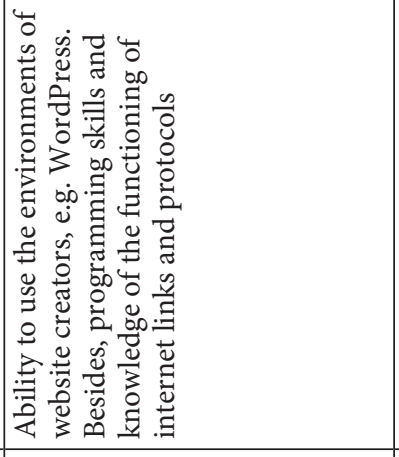 & 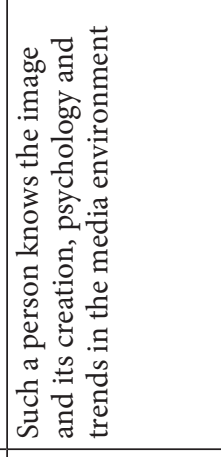 \\
\hline 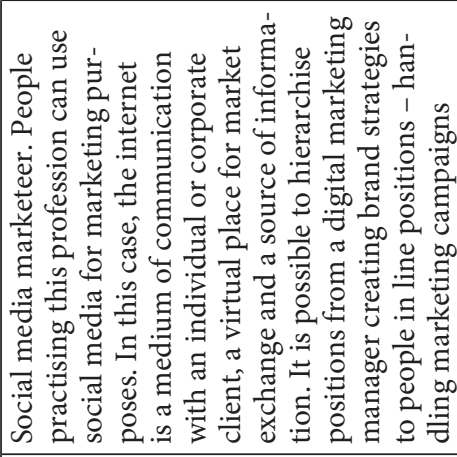 & 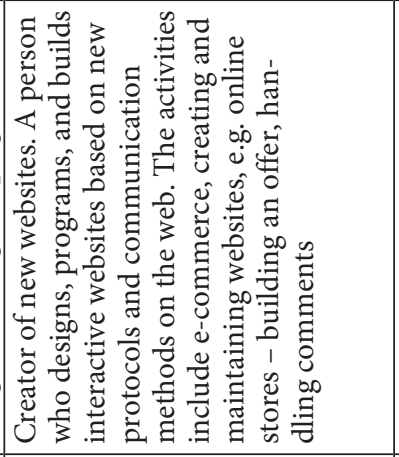 & 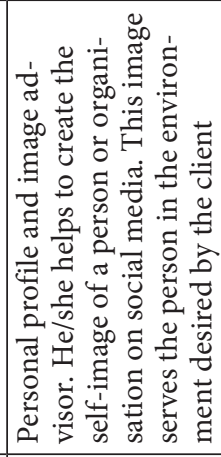 \\
\hline 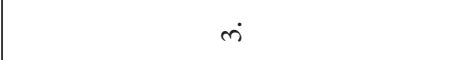 & +ن & in \\
\hline
\end{tabular}




\begin{tabular}{|c|c|c|c|c|}
\hline 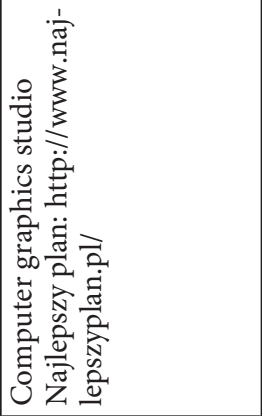 & 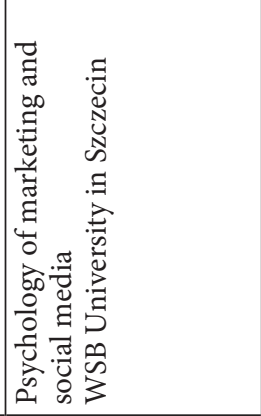 & 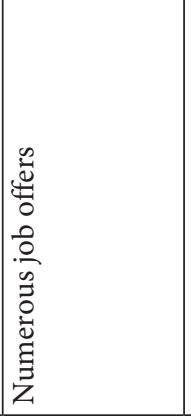 & 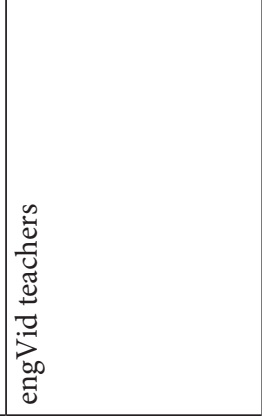 & 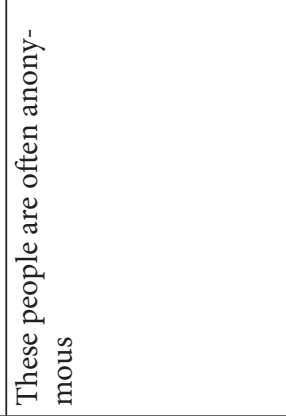 \\
\hline 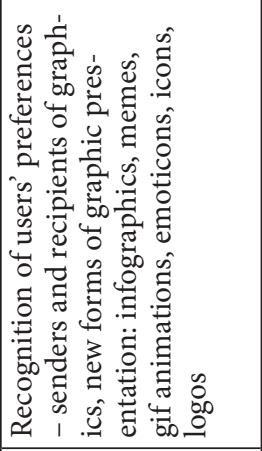 & 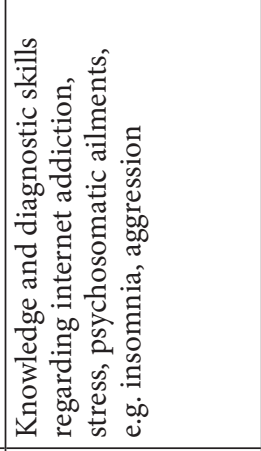 & 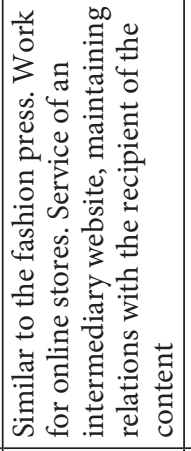 & 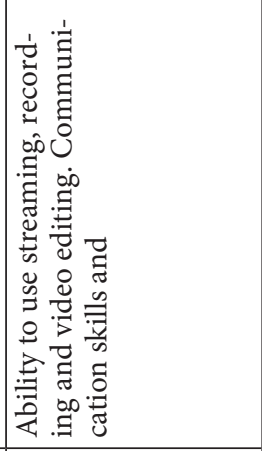 & 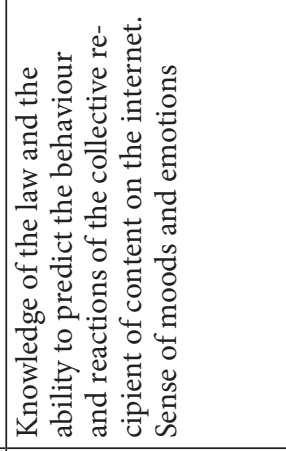 \\
\hline 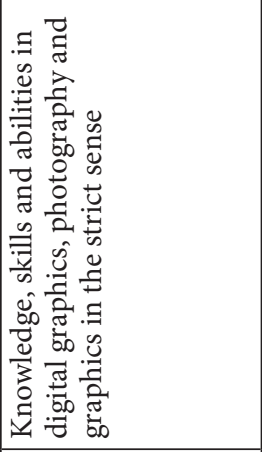 & 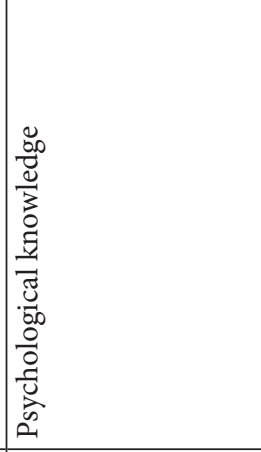 & 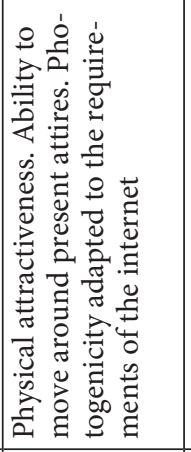 & 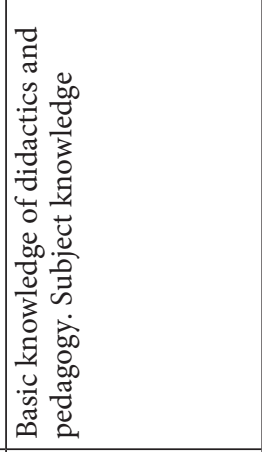 & 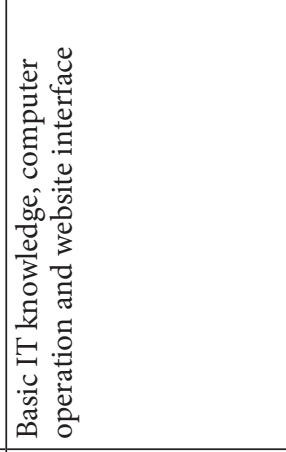 \\
\hline 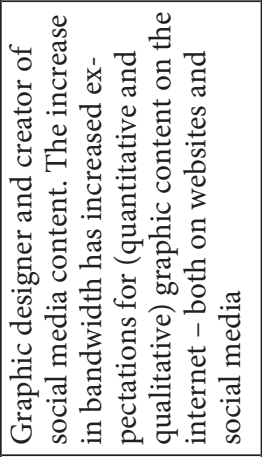 & 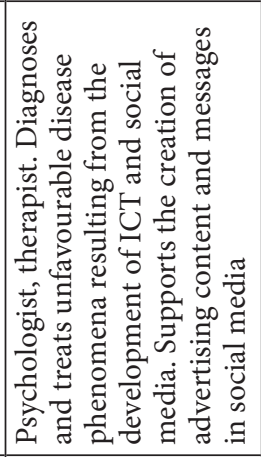 & 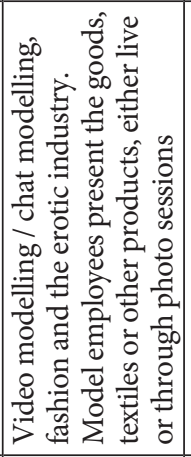 & 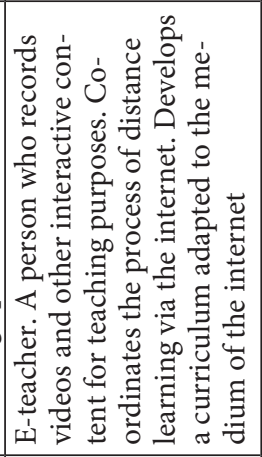 & 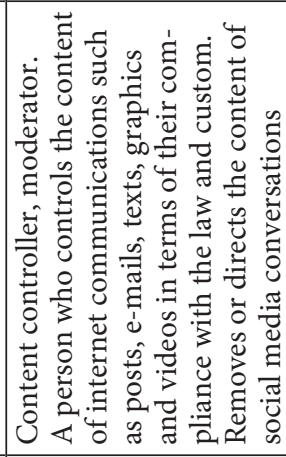 \\
\hline$\dot{0}^{\circ}$ & $\mathbf{N}^{\circ}$ & $\infty$ & $\sigma^{\circ}$ & 이 \\
\hline
\end{tabular}




\begin{tabular}{|c|c|c|c|}
\hline 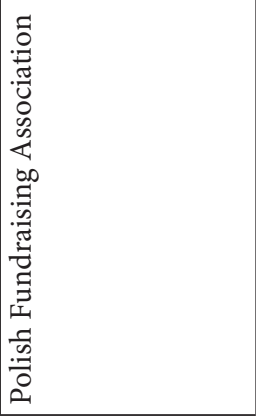 & 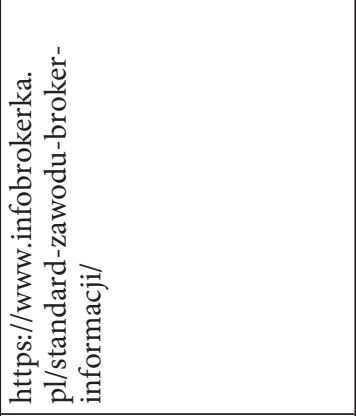 & 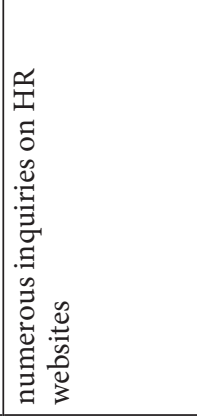 & 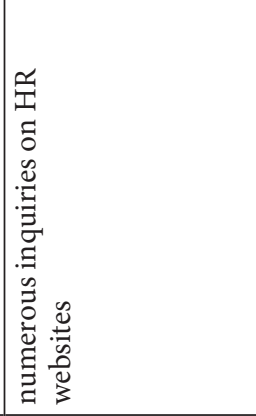 \\
\hline 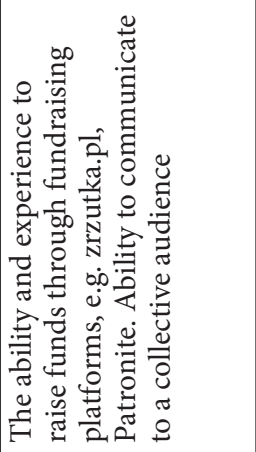 & 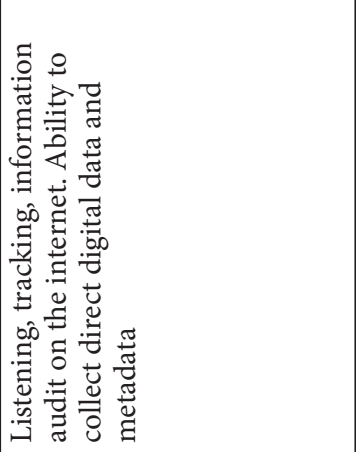 & 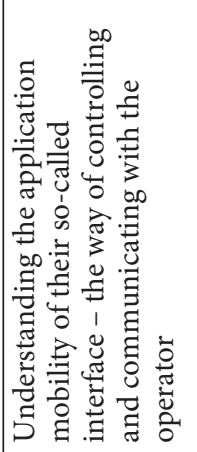 & 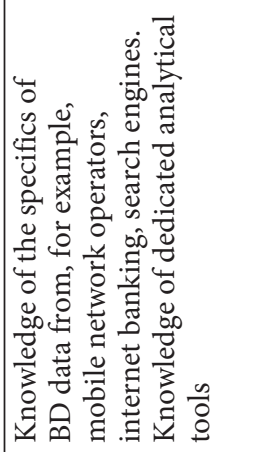 \\
\hline 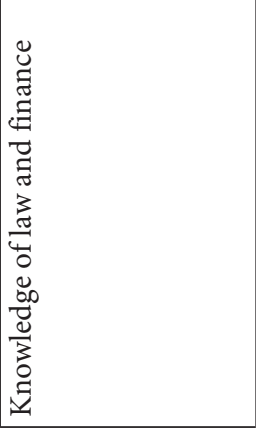 & 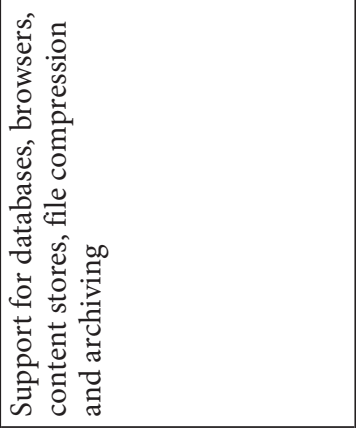 & 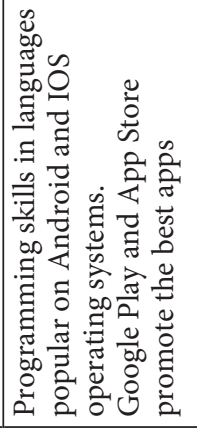 & 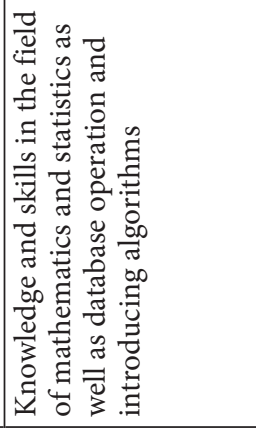 \\
\hline 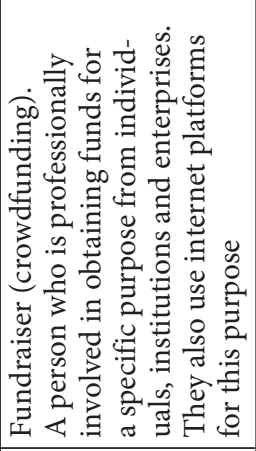 & 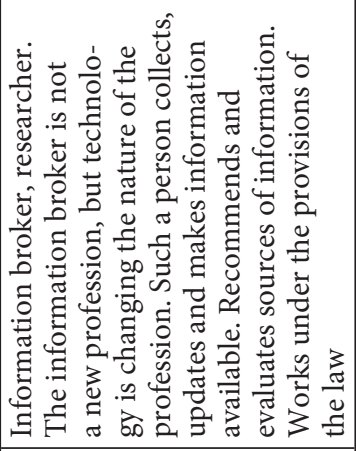 & 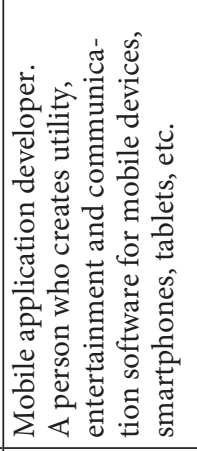 & 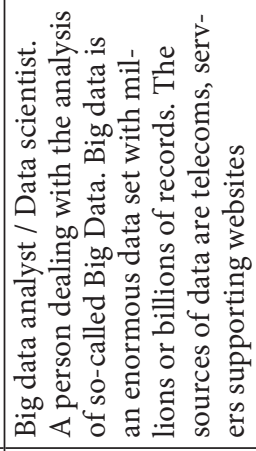 \\
\hline$\exists$ & 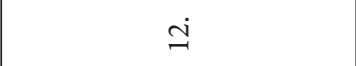 & $\stackrel{M}{\longrightarrow}$ & $\exists$ \\
\hline
\end{tabular}




\begin{tabular}{|c|c|c|c|c|c|}
\hline \multirow{6}{*}{ 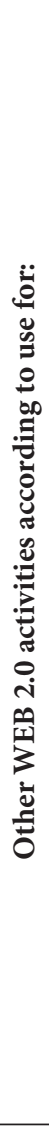 } & 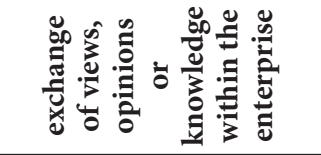 & $\exists$ & $\vec{a}$ & $\stackrel{\sharp !}{\bullet}$ & $\stackrel{ }{\mathrm{m}}$ \\
\hline & 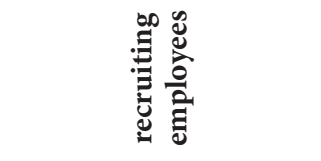 & $\stackrel{\sim}{2}$ & $\overrightarrow{\mathrm{I}}$ & 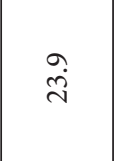 & $\begin{array}{l}n \\
\text { n̊n }\end{array}$ \\
\hline & 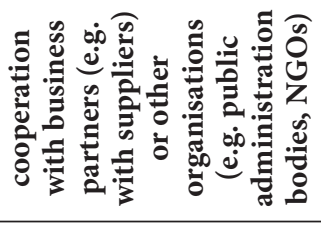 & $\stackrel{m}{\sim}$ & $\stackrel{\infty}{\stackrel{\infty}{\circ}}$ & $\hat{\sigma}$ & $\begin{array}{l}\infty \\
\stackrel{n}{0}\end{array}$ \\
\hline & 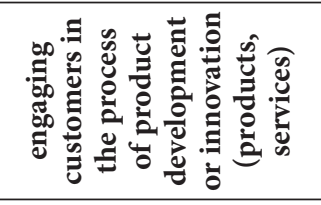 & $\hat{\sigma}$ & $\underset{\infty}{\sim}$ & $\stackrel{\sim}{\sim}$ & $\begin{array}{l}\stackrel{+}{0} \\
\stackrel{\infty}{\sim}\end{array}$ \\
\hline & 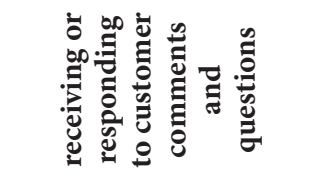 & $\hat{\mathrm{i}}$ & $\begin{array}{l}n ? \\
\stackrel{n}{n}\end{array}$ & $\begin{array}{l}\infty \\
\stackrel{\infty}{\sim} \\
\stackrel{\sim}{N}\end{array}$ & 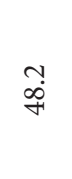 \\
\hline & 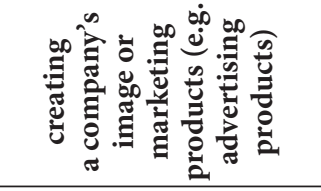 & $\stackrel{n}{\stackrel{n}{m}}$ & $\stackrel{\sim}{\grave{\lambda}}$ & $\begin{array}{l}\infty \\
\stackrel{f}{f}\end{array}$ & 웅 \\
\hline \multirow{5}{*}{ 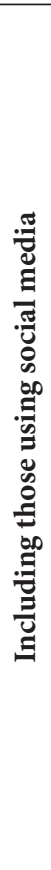 } & 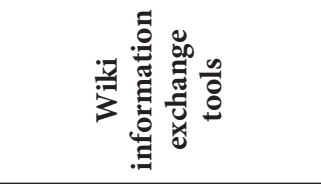 & $\stackrel{n}{i}$ & $\stackrel{\infty}{-}$ & $\hat{m}$ & $\stackrel{\infty}{\underset{+}{-}}$ \\
\hline & 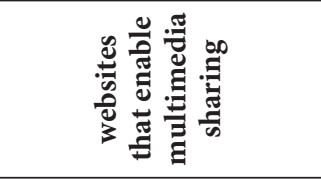 & $\stackrel{m}{m}$ & $\stackrel{n}{0}$ & 气̊̀ & 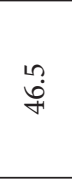 \\
\hline & 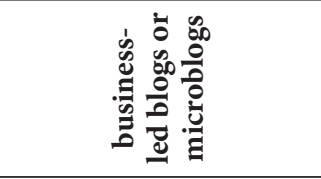 & $\begin{array}{l}\infty \\
i \\
i\end{array}$ & $\stackrel{\curvearrowright}{f}$ & $\stackrel{\infty}{\wedge}$ & $\stackrel{\circ}{\underset{\sim}{N}}$ \\
\hline & 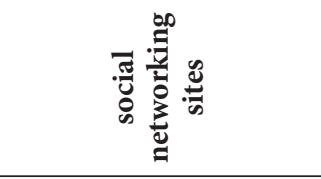 & $\ddot{\ddot{n}}$ & $\underset{\sim}{\stackrel{n}{n}}$ & $\begin{array}{l}0 \\
\dot{q}\end{array}$ & $\hat{\sigma}$ \\
\hline & 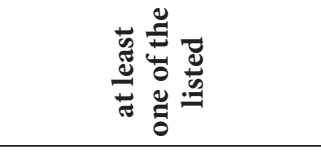 & $\begin{array}{l}\dot{0} \\
\dot{m}\end{array}$ & $\stackrel{\sim}{m}$ & 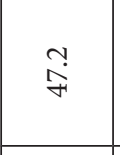 & $\stackrel{n}{\circ}$ \\
\hline & : & 胥 & 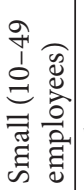 & 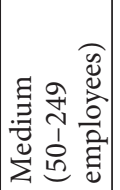 & 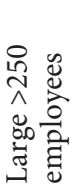 \\
\hline
\end{tabular}


$32.5 \%$ of enterprises admit to creating a company image or product marketing (e.g. advertising products) via social media and the internet; by class size (small - medium - large), this action is taken by $29.2 \%, 42.8 \%, 66.0 \%$ of companies. Data from the Central Statistical Office indicate a continuous increase in the interest of enterprises in WEB 2.0; in $2014,18.4 \%$ of enterprises used services on social media. It was $16.6 \%$ of small companies, 24.8 of medium companies, and 39.7 large companies (GUS) by company size. The very category of social media appeared in the statistics of the Central Statistical Office in 2014 , and there is a visible increase in the interest of enterprises in being active in this area.

The set of activities on the WEB 2.0 internet sphere presented in Table 3 should also include those undertaken by the public service sector related to the administration of local government, central and regional institutions, and non-governmental organisations. For a long time in many Western countries, a trend of governance has been observed, i.e. new public management (Sivarajah, Irani, Weerakkody, 2015).

These phenomena include the increasingly popular internal marketing activities and communication by city authorities, councillors and city activists with residents. The data show that both the public sector and business enterprises create a demand for professions related to the evolving internet 2.0 to adapt communication and marketing channels. Organisations, from public to commercial, through communication with the social and business environments through WEB 2.0, can perform the many tasks and functions assigned to them: information, education, persuasion and strengthening a position (marketing). Skilful communication via SM can significantly contribute to building the competitive advantage of the enterprise. Such activities in creating the image of an organisation and promoting its products are supplemented by collecting data on customers' behaviour on the web, unavailable through traditional marketing research methods.

\section{Summary and conclusions}

The WEB 2.0 phenomenon, due to its multidimensional impact and economic, technological and socio-cultural effects, is still a subject of research and discussion. The concept of WEB 2.0 should be treated as mature, but at the same time also new and developing as its implications are still not fully understood in the various spheres of life of an individual and organisation. Given the contemporary phenomena at the interfaces between technology, economy and society, the term WEB 2.0 is chronological because it succeeds WEB 1.0, and its consequence is WEB 3.0. Thus, new and evolving training needs emerge. Changes in the labour market and the requirements for having further generations of competencies extended via the internet are associated with changes in the ethos and organisation of work. An example is the phenomenon of so-called digital nomads: people who can work remotely and migrate to places they find attractive in quality and living conditions. Remote and self-employed work resulting in a service or an intangible product (program code, graphics, text, editing, work) does not require a spatial link. In the Covid SARS pandemic context, the need for remote work has become more common, making some employers and permanent workers aware of its advantages and disadvantages. The consequence of this are forms of virtual enterprises in which the material base is not as important as the competencies and qualifications of the people who comprise it. There are also opinions that the specificity of the internet 2.0 labour market has the advantage of reducing so-called outsider stress. "Age, sex, appearance or nationality 
do not matter. What counts is the willingness, commitment and the ability to solve a task (not necessarily qualifications)" (Stefaniak, 2014: 178). The specificity of working in the professions related to WEB 2.0 and 3.0 is the opening of opportunities for people who, from resources of knowledge (hobbyists, enthusiasts) and experience gained individually, resources of skills and often material objects, e.g. collections of clothes, books, films, etc. with the participation of informal competencies, not necessarily learned in a traditional way, can create a media product and monetise it.

The professions described in Table 2 require numerous competencies, which can be classified as soft in light of the quoted literature. Digital competencies constitute the canvas and basic competencies from other fields - often validated by qualifications for a given profession - using metaphorical terms such as 'harder'. Competencies related to WEB 2.0 and 3.0 are a less coherent and more 'fuzzy' set. By systematising them, some of them can be classified as abilities or interpersonal communication skills. Inborn empathy and an extroverted personality can help in this respect. In addition to the innate foundation, appropriate additional training in communication, ethics, techniques of exerting influence and emerging internet rules of behaviour (netiquette) are needed.

The second area of competency is the ability to analyse the behaviour of people and communities in the network. In this case, knowledge and skills in the field of cognitive communication come to the rescue - understanding the operation of the mind, building models of individual mental functions: reasoning, perception, memory, awareness, emotions, moral sensitivity, understanding language, etc.

The next sub-group of competencies is self-creation: taking care of one's image, managing it and, on a broader scope, building a personal brand. This area is of particular importance for those who publish materials (text, podcast, video, graphics) in which they are a leading and presenting figure. Gaining fans and subscriptions to commercialise online activity is closely related to this.

Another set of more structured competencies is collecting and processing information, primary digital data and metadata. Their volume differs from the previous generation of the internet, and the capacity is now measured in exabytes. They require a different approach and analysis than for data known so far.

Going beyond amateur and community 2.0 activities requires contacts with the business environment. Its skilful management can be carried out in person or outsourced. Hence, the area of maintaining relationships beyond social media opens up. Competencies specific to the internet developer industry become indispensable here. Each of the WEB 2.0 services has a panel and service subpages visible only to the creator and predefined traffic analyses, rules and principles of remuneration. Regardless of this, creating so-called collaborative content, product placement, reviewing and acting as an influencer broaden the requirements in this area of competency.

The importance of the internet at the junction of social spheres and the economy will undoubtedly increase. However, geopolitical threats related to sharing virtual space, especially between China and the United States, have appeared. Global networks may lose their transnational reach. For instance, US President Trump announced the idea of a clean network, and the EU has put forward claims against internet tycoons (so-called Big Tech). According to their assumptions, the WEB 3.0 internet and subsequent generations will not significantly change the achievements of WEB 2.0. Semantic networks and artificial intelligence seem to reduce the human presence on the internet. Future generations 
of the WEB 3.0+ internet will support people in their everyday lives even more than today and expand the socio-virtual sphere if there are no attempts to divide and limit it. It can be assumed that two trends will clash there. On the one hand, technology will allow for the emergence of independent organisations and certain forms of internet democracy and exchange based on virtual currencies: separation from traditional state and national structures. On the other hand, some human activity will be eliminated from the internet. For example, customer service will be performed by bots and artificial intelligence.

\section{References}

Berek, J. (2016). Identyfikacja pożądanych kompetencji pracowników na przykładzie przedsiębiorstw branży lotniczej regionu bielsko-bialskiego. Zeszyty Naukowe Małopolskiej Wyższej Szkoły Ekonomicznej w Tarnowie, 29(1), 13-25.

Berners-Lee, T. (1998; 2020, 15 November). The World Wide Web: A very short personal history. Retrieved from: http://www.w3.org/People/Berners-Lee/ShortHistory.htm

Boyatzis, R.E. (1982). The Competent Manager: A Model for Effective Performance. New York: John Wiley\&Sons.

Collins Dictionary. (2020, 15 November). https://www.collinsdictionary.com

DuBrin, A. (2008). Essentials of Management. Mason. OH: South-Western Cengage Learning.

Filipowicz, G. (2004). Zarzadzanie kompetencjami zawodowymi. Warszawa: PWE.

Garavan, T., McGuire, D. (2001). Competences \& Workplace Learning: Some Reflections on the Rhetoric \& the Reality. Journal of Workplace Learning, 13(4), 144-164.

Karakas, F., (2009). Welcome to World 2.0: New Digital Ecosystem. Journal of Business Strategy, 30(4), $22-30$.

Kossowska, M., Sołtysińska, I. (2002). Szkolenia pracowników a rozwój organizacji. Kraków: Oficyna Ekonomiczna.

Kwiatkowski, S.M., Woźniak, I. (2003). Krajowe standardy kwalifikacji zawodowych. Projektowanie i stosowanie. Warszawa: MGiPS.

Woodall, J., Winstanley, D. (1998). Management Development: Strategy \& Practice. Oxford: Blackwell.

Kwiatkowski, S.M. (2014). Od kompetencji do zintegrowanego systemu kwalifikacji. Ruch Pedagogiczny, 4, 25-33.

Management Charter Initiative. (1990). Occupational Standards for Managers: Management I and Assessment Guidance, MCI. London.

McClelland, D.C. (1973). Testing for Competence, rather than Intelligence. American Psychologist, 28, $1-14$.

Mikuła, B., Pietruszka-Ortyl, A. (2007). Kompetencje pracowników w perspektywie strategicznego zarządzania wiedzą w przedsiębiorstwie. Zeszyty Naukowe AE w Krakowie, 747, 49-73.

Model ewolucji internetu: wersja 0.3. (2010). Retrieved from: http://networkeddigital.com/2010/03/28/ model-ewolucji-internetu-wersja-0-3/

NCVQ. (1997). National Council for Vocational Qualifications.

New, G.E. (1996). Reflections: A three-tier model of organizational competences. Journal of Managerial Psychology, 11, 8, 44-51

Nordhaug, O., Gronhaug, K. (1992). Strategy and Competence in Firms. European Performance. NY: Wiley Sons.

O’Reilly, T. (2005; 2020, 15 November). What Is Web 2.0? Retrieved from: http://oreilly.com/web2/archive/what-is-web-20.html

Orlińska-Gondor, A. (2006). Zarządzanie ludźmi oparte na pojęciu kompetencji. In: L. Zbiegień-Maciąg (ed.), Nowe tendencje i wyzwania w zarządzaniu personelem. Kraków: Oficyna Ekonomiczna Grupa Wolters Kulwer, 168-190. 
Rostowski, T. (2002). Kompetencje jako jakość zarządzania zasobami ludzkimi. In: A. Sajkiewicz (ed.), Jakość zasobów firmy. Kultura, kompetencje, konkurencyjność. Warszawa: Wydawnictwo POLTEXT.

Rudewicz, J. (2019). Model ekonomii współpracy w koncepcji miast Smart City 3.0. Przedsiębiorczość Edukacja [Entrepreneurship - Education], 15(2), 153-170.

Schroder, H.M. (1989). Managerial Competences: The key to excellence. The Academy of Management Review, 15(4), 713-715.

Sivarajah, U., Irani, Z., Weerakkody, V. (2015). Evaluating the use and impact of Web 2.0 technologies in local government. Government Information Quarterly, 32, 473-487.

Spencer, L.M., Spencer, S.M. (1993). Competence at Work. Models for Superior. Willey.

Spivack, N. (2011; 2020, 15 November). Web 3.0: The Third Generation Web is Coming. Retrieved from: http://lifeboat.com/ex/web.3.0

Stefaniak, I.M. (2014). Technologia a praca: nowe kompetencje a stare reguły, czyli o wirtualnym świecie, jego możliwościach i wymaganiach. Studia Ekonomiczne, 173-181.

Training Standards Agency. (2000). Definition as in S. Horton Introduction - The Competency Movement: its Origins and Impact on the Public Sector. International Journal of Public Sector Management, 13(4), 7-14.

Jacek Rudewicz, PhD, University of Szczecin, Institute of Spatial Management and Socio-Economic Geography. Faculty of Finance and Management Economics. He graduated from geography with a specialisation in socio-economic geography, management and marketing, and economics. In his academic work he deals with urban studies, sustainable development, regional and local development.

ORCID: https://orcid.org/0000-0002-2659-4754

\section{Address:}

Uniwersytet Szczeciński

Wydział Ekonomii Finansów i Zarządzania

Instytut Gospodarki Przestrzennej i Geografii Społeczno-Ekonomicznej

ul. Mickiewicza 64

71-101 Szczecin, Polska

e-mail: jacek.rudewicz@usz.edu.pl

Krzysztof Sala, PhD, Pedagogical University of Krakow. Faculty of Political Science. Institute of Law and Economics Department of Entrepreneurship and Social Innovation. Academic interests: economic policy of Poland and European countries, social policy, environmental policy and sustainable development, tourism policy, entrepreneurship and entrepreneurs in Poland and abroad, management of small and medium-sized companies.

ORCID: https://orcid.org/0000-0002-7614-9309

\section{Address:}

Uniwersytet Pedagogiczny im. Komisji Edukacji Narodowej w Krakowie

Instytut Prawa i Ekonomii

Katedra Przedsiębiorczości i Innowacji Społecznych

ul. Podchorążych 2

30-084 Kraków, Polska

e-mail: krzysztof.sala@up.krakow.pl 